\title{
Can we reduce the spread of HIV infection by suppressing herpes simplex virus type 2 infection?
}

Anne Buvé

Address: Department of Microbiology, Institute of Tropical Medicine, Nationalestraat 155, B-2000 Antwerp, Belgium

Email: abuve@itg.be

FI000 Medicine Reports 2010, 2:4I (doi:I0.34I0/M2-4I)

The electronic version of this article is the complete one and can be found at: http://fl000.com/reports/medicine/content/2/4 I

\begin{abstract}
Overwhelming evidence from observational epidemiological studies indicates that herpes simplex virus type 2 (HSV-2) infection enhances the risk of acquiring HIV infection. Studies of genital shedding of HIV have suggested that HSV-2 infection also increases the onward transmission of HIV-I by HIV/ HSV-2 co-infected patients. Several randomized controlled trials were initiated to assess the impact of HSV-2 suppressive therapy on the acquisition of HIV infection by HSV-2 infected men and women, and on the onward transmission of HIV by HSV-2/HIV co-infected men and women. In the past 2 years the results of these trials have been published. HSV-2 suppressive therapy was not found to have any effect on HIV acquisition nor on onward transmission of HIV. However, suppressive therapy with acyclovir was found to slow down disease progression in HIV/HSV-2 co-infected patients. The effect was rather modest and cost-effectiveness studies are needed to assess whether HSV-2 suppressive therapy has a place in the management of HIV-I infected patients, especially in low and middle income countries.
\end{abstract}

\section{Introduction and context}

The World Health Organization and The United Nations Joint Programme on HIV/AIDS (UNAIDS) estimated that in 2008, 2.7 million people became newly infected with HIV, of whom 1.9 million were living in subSaharan Africa [1]. Since the beginning of this century, considerable progress has been made in the scaling up of antiretroviral treatment in low and middle income countries. However, coverage remains suboptimal and new HIV infections continue to outnumber patients who are put on antiretroviral treatment [2]. It is clear that HIV treatment programs are not sustainable unless the tide of new HIV infections is stemmed.

Strategies to reduce the spread of HIV infection can be broadly categorized into behavioural interventions and biomedical interventions. The latter interventions aim to reduce the probability of transmission of HIV during sexual intercourse and one of the most promising interventions in this field was the control of other sexually transmitted infections (STIs) as they have been shown to facilitate the transmission of HIV [3]. Several randomized trials have been conducted to assess the impact of STI control on the incidence of HIV infection, with conflicting results. It appeared that the impact of STI control on the spread of HIV is dependent on the stage of the HIV epidemic, with a larger impact in earlier stages of the epidemic [4]. Moreover, it became clear that infection with herpes simplex virus type 2 (HSV-2) a viral STI that cannot be controlled by early detection and treatment of infected persons, plays an overwhelming role in the spread of HIV, especially in sub-Saharan Africa, where the prevalence of HSV-2 infection in adults in the general population ranges from $30 \%$ to $80 \%$ in women and from $10 \%$ to $50 \%$ in men [5]. A meta-analysis of longitudinal studies found that men and women who are infected with HSV-2 have a three-fold increased risk of acquiring HIV infection [6]. Using this relative risk and data on prevalence of HSV-2 infection, it has been estimated that in sub-Saharan Africa, 38-60\% of new HIV 
infections in women and $8-49 \%$ of new infections in men may be attributable to HSV-2 infection [6]. In addition, studies on shedding of HIV and HSV-2 in the genital tract have shown that reactivation of HSV-2 infection is associated with increased shedding of HIV, suggesting that HSV-2 infection increases the infectivity of HIV/HSV-2 co-infected men and women [7-10].

A reduction in incidence and prevalence of HSV-2 infection could thus have a considerable impact on the incidence of HIV infection. However, apart from behaviour change interventions and condom use, there are very few options to control HSV-2 infection with biomedical interventions. The only vaccine with some proven efficacy prevents HSV-2 acquisition in women who are not infected with HSV-1, but does not prevent acquisition in men, or in women who are infected with HSV-1 [11]. This vaccine is thus of very limited use in low and middle income countries where the prevalence of HSV-1 among young people and adults is still very high. To date the only alternative strategy is suppressive therapy with acyclovir or valacyclovir, which has been shown to decrease episodes of reactivation of HSV-2 infection and transmission of HSV-2 [12,13]. Several randomized controlled trials were initiated to assess the impact of HSV-2 suppressive therapy on the acquisition of HIV infection by HSV-2 infected men and women, and on the onward transmission of HIV by HSV-2/HIV coinfected men and women. In the past 2 years the results of these trials have been published, and it is time now to take stock.

\section{Recent advances}

Does suppressive therapy reduce the risk of HIV infection in HSV-2 infected men and women?

Two trials have assessed the effect of HSV-2 suppressive treatment with acyclovir $400 \mathrm{mg}$ twice daily on HIV acquisition $[14,15]$. Study populations included women in Tanzania at high risk of HIV infection; women at lower risk of HIV infection in South Africa, Zimbabwe and
Zambia; and men who have sex with men in Peru and in the USA. Suppressive treatment with acyclovir reduced the incidence of genital ulcerations but did not have any effect on HIV incidence (Table 1).

Whenever the results of a trial are negative, two major questions are raised: (a) was the intervention that was tested the right one; and (b) was there an effect that was not measured? The above trials were powered to detect a $50 \%$ protective effect of suppressive therapy with acyclovir and had sufficient endpoints to detect such effect. The two trials might have missed a modest effect of more limited public health significance. Suboptimal adherence to the study drugs could have attenuated any difference in HIV incidence between the two study arms. In both trials very high adherence levels were achieved. In the Tanzanian trial there was an effect in those women who took more than $90 \%$ of the prescribed medication, but it was not statistically significant (rate ratio 0.58 , 95\% confidence interval [CI] 0.25-1.38) and such effect was not found in the trial by Celum et al. [15] (hazard ratio [HR] 1.0, 95\% CI 0.67-1.50).

The most likely explanation for the lack of effect is that the intervention was not right. The authors of both papers considered the possibility that valacyclovir or higher dose acyclovir might have been a better choice for suppressive therapy. Studies on the effects on herpes recurrences of acyclovir and of valacyclovir, however, suggest that both drugs may have similar effects and that it is unlikely that a larger impact on HIV incidence would have been found with valacyclovir. The most likely explanation is that the concept of the intervention was not right and that suppressing clinical and subclinical reactivation of HSV-2 infection is not enough to reduce the vulnerability to HIV infection associated with HSV-2 infection. Indeed, a study published in 2009 found evidence that HIV receptor-positive inflammatory cells persist in the genitalia for a very long time after healing of reactivation [16].

Table I. Summary of trials that assessed the impact of suppressive therapy with acyclovir on HIV acquisition

\begin{tabular}{|c|c|c|c|c|c|c|}
\hline \multirow[b]{2}{*}{ Study population } & \multirow[b]{2}{*}{ Site } & \multirow[b]{2}{*}{ Total $(n)$ enrolled } & \multicolumn{2}{|c|}{ Incidence of HIV per 100 pyr } & \multirow[b]{2}{*}{ Rate ratio/HR $(95 \% \mathrm{Cl})$} & \multirow[b]{2}{*}{ Reference } \\
\hline & & & Treatment group & Placebo group & & \\
\hline $\begin{array}{l}\text { Women at higher } \\
\text { risk of HIV }\end{array}$ & Tanzania & 821 & 4.44 & 4.12 & I.08 (0.64-I.83) & [7] \\
\hline $\begin{array}{l}\text { Women at lower } \\
\text { risk of HIV }\end{array}$ & $\begin{array}{l}\text { South Africa, } \\
\text { Zimbabwe, Zambia }\end{array}$ & 1358 & 4.9 & 3.1 & $1.53(0.95-2.46)$ & [8] \\
\hline MSM & $\begin{array}{l}\text { Peru } \\
\text { USA }\end{array}$ & $\begin{array}{l}1355 \\
459\end{array}$ & $\begin{array}{l}3.2 \\
2.5\end{array}$ & $\begin{array}{l}3.8 \\
2.2\end{array}$ & $\begin{array}{l}0.82(0.48-1.4 I) \\
I .09(0.36-3.24)\end{array}$ & [8] \\
\hline
\end{tabular}

$\mathrm{Cl}$, confidence interval; HR, hazard ration; MSM, men who have sex with men; pyr, person-years. 
Does suppressive therapy reduce onward transmission of HIV infection by HSV-2IHIV co-infected men and women? Several randomized trials published in recent years found that suppressive therapy with acyclovir or valacyclovir reduced plasma HIV viral load and genital shedding of HIV-1 RNA in HIV-infected women and men who were co-infected with HSV-2 [17-21]. This suggests that suppressive therapy of HSV-2 infection could reduce the infectivity of HIV/HSV-2 co-infected persons. However, the proof of the pudding is in the eating. The Partners in Prevention HSV/HIV Transmission Study directly assessed the effects of suppressive therapy with acyclovir on onward transmission of HIV from an HIV/ HSV-2 co-infected person to his/her HIV uninfected stable partner [22]. Study participants taking $400 \mathrm{mg}$ acyclovir twice daily had significantly less episodes of genital ulcers than study participants in the placebo group. They also had a significantly lower plasma HIV viral load. Yet, there was no difference in HIV transmission: in the intention-to-treat analysis the incidence of HIV infection was the same in the intervention group and the placebo group, 2.7 per 100 person-years (HR 0.99 , 95\% CI 0.71-1.40).

The study was powered to detect a 50\% reduction in HIV transmission, so a modest effect might have been missed that would have been of limited public health significance. The most likely explanation for the disappointing result is that the reduction in plasma HIV viral load was just not enough to reduce infectivity. During the followup period the mean plasma viral load was 0.25 log lower in the acyclovir group compared to the placebo group [22]. An observational study of HIV discordant couples in Uganda suggests that larger reductions in plasma viral load are needed to have a substantial effect on onward transmission of HIV. In this study the mean plasma viral load was $4.48 \mathrm{log}$ in HIV-1 infected subjects whose partner seroconverted and $3.89 \log$ in HIV-1 infected subjects whose partner did not seroconvert [23].

The Partners in Prevention HSV/HIV Transmission Study was also the first study that directly assessed the longterm effects of HSV-2 suppressive therapy on disease progression [24]. In the patients who took acyclovir, the decline in CD4 cell count was slower, initiation of antiretroviral treatment was delayed, and mortality was reduced compared with patients in the control group.

\section{Implications for clinical practice}

The trials with HSV-2 suppressive therapy have not found any effect on HIV acquisition nor on HIV transmission. Consequently, suppressive therapy with acyclovir and valacyclovir does not have any place in HIV prevention. This does not imply, however, that there is no interaction between HSV-2 infection and HIV-1 infection. The evidence - though observational - that HSV-2 enhances the transmission of HIV is overwhelming. The problem lies in the lack of biomedical interventions that can substantially reduce the incidence and prevalence of HSV-2 infection. Meanwhile, valuable lessons have been learned from these trials and we have made progress in our understanding of the mechanisms underlying the increased vulnerability to HIV-1 infection associated with HSV-2 infection.

Suppressive therapy with acyclovir had a beneficial effect on disease progression in HIV/HSV-2 co-infected subjects. However, this benefit was rather modest and cost-effectiveness analyses will have to be done to assess whether acyclovir can have a place in the management of HIV-infected patients in low- and middle-income countries [25].

\section{Abbreviations}

$\mathrm{CI}$, confidence interval; HR, hazard ratio; HSV, herpes simplex virus; STI, sexually transmitted infection.

\section{Competing interests}

The author declares that she has no competing interests.

\section{References}

I. UNAIDS: AIDS Epidemic Update. UNAIDS/09.36E / JCI700E. Geneva: Joint United Nations Programme on HIVIAIDS; 2009. [http://data. unaids.org/pub/Report/2009/JCI700_Epi_Update_2009_en.pdf]

2. World Health Organization: Towards Universal Access: Scaling Up Priority HIVIAIDS Interventions in the Health Sector: Progress Report 2009. Geneva: World Health Organization; 2009.

3. Fleming DT, Wasserheit JN: From epidemiological synergy to public health policy and practice: the contribution of other sexually transmitted diseases to sexual transmission of HIV infection. Sex Transm Infect 1999, 75:3-17.

4. Korenromp EL, White RG, Orroth KK, Bakker R, Kamali A, Serwadda D, Gray RH, Grosskurth H, Habbema JD, Hayes RJ: Determinants of the impact of sexually transmitted infection treatment on prevention of HIV infection: a synthesis of evidence from the Mwanza, Rakai, and Masaka intervention trials. J Infect Dis 2005, I9I(Suppl I):SI68-78.

5. Weiss $\mathrm{H}$ : Epidemiology of herpes simplex virus type $\mathbf{2}$ infection in the developing world. Herpes 2004, I I(Suppl I): 24A-35A

6. Freeman EE, Weiss HA, Glynn JR, Cross PL, Whitworth JA, Hayes RJ: Herpes simplex virus 2 infection increases HIV acquisition in men and women: systematic review and meta-analysis of longitudinal studies. AIDS 2006, 20:73-83.

7. Schacker T, Ryncarz AJ, Goddard J, Diem K, Shaughnessy M, Corey L: Frequent recovery of HIV-I from genital herpes simplex virus lesions in HIV-I-infected men. JAMA I998, 280:6I-6.

8. Mbopi-Kéou FX, Grésenguet G, Mayaud P, Weiss HA, Gopal R, Matta M, Paul JL, Brown DW, Hayes RJ, Mabey DC, Bélec L: Interactions between herpes simplex virus type 2 and human immunodeficiency virus type I infection in African women: opportunities for intervention. J Infect Dis 2000, I82:1090-6.

9. McClelland RS, Wang CC, Overbaugh J, Richardson BA, Corey L, Ashley RL, Mandaliya K, Ndinya-Achola J, Bwayo JJ, Kreiss JK: Association between cervical shedding of herpes simplex virus and HIV-I. AIDS 2002, I 6:2425-30. 
10. Cowan FF, Pascoe SJ, Barlow KL, Langhaug LF, Jaffar S, Hargrove JW, Robinson NJ, Latif AS, Bassett MT, Wilson D, Brown DW, Hayes RJ: Association of genital shedding of herpes simplex virus type 2 and HIV-I among sex workers in rural Zimbabwe. AIDS 2006, 20:26I-7.

II. Stanberry LR, Spruance SL, Cunningham AL, Bernstein DI, Mindel A, Sacks S, Tyring S, Aoki FY, Slaoui M, Denis M, Vandepapeliere P, Dubin G; GlaxoSmithKline Herpes Vaccine Efficacy Study Group: Glycoprotein-D-adjuvant vaccine to prevent genital herpes. N Engl J Med 2002, 347:1652-61.

FI000 Factor 4.8 Must Read

Evaluated by Jeffrey Cohen 25 Nov 2002, Barry Rouse 09 Jan 2003

12. Corey L, Wald A, Patel R, Sacks SL, Tyring SK, Warren T, Douglas JMJr, Paavonen J, Morrow RA, Beutner KR, Stratchounsky LS, Mertz G, Keene ON, Watson HA, Tait D, Vargas-Cortes M; Valacyclovir HSV Transmission Study Group: Once daily valacyclovir to reduce the risk of transmission of genital herpes. New Engl J Med 2004, 350:11-20.

13. Corey L, Ashley R; Valacyclovir HSV Transmission Study Group: Prevention of herpes simplex virus type 2 transmission with antiviral therapy. Herpes 2004, I I (Suppl 3): I70A-4A.

14. Watson-Jones D, Weiss HA, Rusizoka M, Changalucha J, Baisley K, Mugeye K, Tanton C, Ross D, Everett D, Clayton T, Balira R, Knight L, Hambleton I, Le Goff J, Belec L, Hayes R; HSV trial team; Steering and Data Monitoring Committees: Effect of herpes simplex suppression on incidence of HIV among women in Tanzania. New Engl J Med 2008, 358:1560-7I.

FI000 Factor 8.3 Exceptional

Evaluated by Anne Buve 09 Apr 2008, Nicola Low 15 Apr 2008, Sheena McCormack 10 Sep 2008, Bryan Larsen 05 Jan 2009

15. Celum C, Wald A, Hughes J, Sanchez J, Reid S, Delany-Moretlwe S, Cowan F, Casapia M, Ortiz A, Fuchs J, Buchbinder S, Koblin B, Zwerski S, Rose S, Wang J, Corey L; HPTN 039 Protocol Team: Effect of aciclovir on HIV-I acquisition in herpes simplex virus 2 seropositive women and men who have sex with men: a randomised, double-blind, placebo-controlled trial. Lancet 2008, 371:2109-19.

FI000 Factor 6.5 Must Read

Evaluated by Nicola Low 03 Jul 2008, Sheena McCormack II Aug 2008, Thomas Hope 08 Jan 2009

16. Zhu J, Hladik F, Woodward A, Klock A, Peng T, Johnston C, Remington M, Magaret A, Koelle DM, Wald A, Corey L: Persistence of HIV-I receptor-positive cells after HSV-2 reactivation is a potential mechanism for increased HIV-I acquisition. Nat Med 2009, 15:886-93.

FI000 Factor 6.0 Must Read

Evaluated by Rupert Kaul 02 Sep 2009
17. Nagot N, Ouédraogo A, Foulongne V, Konaté I, Weiss HA, Vergne L, Defer MC, Djagbaré D, Sanon A, Andonaba JB, Becquart P, Segondy M, Vallo R, Sawadogo A, Van de Perre P, Mayaud P; ANRS I 285 Study Group: Reduction of HIV-I RNA levels with therapy to suppress herpes simplex virus. N Engl J Med 2007, 356:790-9.

FI000 Factor 3.0 Recommended

Evaluated by Susana Asin 17 Jan 2008

18. Baeten JM, Strick LB, Lucchetti A, Whittington WL, Sanchez J, Coombs RW, Magaret A, Wald A, Corey L, Celum C: Herpes simplex virus (HSV-suppressive therapy decreases plasma and genital HIV-I levels in HSV-2/HIV-I coinfected women: a randomized, placebo-controlled, cross-over trial. J Infect Dis 2008, 198:1804-8.

19. Dunne EF, Whitehead S, Sternberg M, Thepamnuay S, Leelawiwat W, McNicholl JM, Sumanapun S, Tappero JW, Siriprapasiri T, Markowitz L: Suppressive acyclovir therapy reduces HIV cervicovaginal shedding in HIV- and HSV-2-infected women, Chiang Rai, Thailand. J Acquir Immune Defic Syndr 2008, 49:77-83.

20. Delany S, Mlaba N, Clayton T, Akpomiemie G, Capovilla A, Legoff J, Belec L, Stevens W, Rees H, Mayaud P: Impact of acyclovir on genital and plasma HIV-I RNA in HSV-2/HIV-I co-infected women: a randomized placebo-controlled trial in South Africa. AIDS 2009, 23:46I-9.

21. Zuckerman RA, Lucchetti A, Whittington WL, Sánchez J, Coombs RW, Magaret A, Wald A, Corey L, Celum C: HSV suppression reduces seminal HIV-I levels in HIV-I/HSV-2 coinfected men who have sex with men. AIDS 2009, 23:479-83.

22. Celum C, Wald A, Lingappa JR, Magaret AS, Wang RS, Mugo N, Mujugira A, Baeten JM, Mullins JI, Hughes JP, Bukusi EA, Cohen CR, Katabira E, Ronald A, Kiarie J, Farquhar C, Stewart G], Makhema J, Essex M, Were E, Fife KH, de Bruyn G, Gray GE, Mclntyre JA, Manongi R, Kapiga S, Coetzee D, Allen S, Inambao M, Kayitenkore K, et al.; Partners in Prevention HSV/HIV Transmission Study Team: Acyclovir and transmission of HIV-I from persons infected with HIV-I and HSV-2. New Engl J Med 2010, 362:427-39.

23. Quinn TC, Wawer MJ, Sewankambo N, Serwadda D, Li C, WabwireMangen F, Meehan MO, Lutalo T, Gray RH: Viral load and heterosexual transmission of human immunodeficiency virus type I. New Engl J Med 2000, 342:92I-9.

24. Lingappa JR, Baeten JM, Wald A, Hughes JP, Thomas KK, Mujugira A, Mugo N, Bukusi EA, Cohen CR, Katabira E, Ronald A, Kiarie J, Farquhar C, Stewart GJ, Makhema J, Essex M, Were E, Fife KH, de Bruyn G, Gray GE, Mclntyre JA, Manongi R, Kapiga S, Coetzee D, Allen S, Inambao M, Kayitenkore K, Karita E, Kanweka W, Delany S, et al. : Daily acyclovir for HIV-I disease progression in people dually infected with HIV-I and herpes simplex virus type 2: a randomised placebo-controlled trial. Lancet 2010, 375:824-33.

25. Buvé A, Lynen L: Treating HIV infection with drugs for HSV-2 infection? Lancet 2010, 375:782-4. 